urn:lsid:zoobank.org:pub:DE003596-2416-4637-9FCD-085FC22BEEE0

\title{
Rare Late Cretaceous phymosomatoid echinoids from the Hannover area (Lower Saxony, Germany)*
}

\author{
NILS SCHLÜTER ${ }^{1,4}$, FRANK WIESE ${ }^{2}$ HELMUT FAUSTMANN ${ }^{3} \&$ PETER GIROD $^{3}$ \\ 1 Georg-August University of Göttingen, Geoscience Centre, Museum, Collections \& Geopark, Göttingen, Germany \\ 2 Georg-August University of Göttingen, Courant Research Centre Geobiology, Göttingen, Germany \\ 3 Berlin, Germany \\ 4 Corresponding author, E-mail: nschlue@gwdg.de \\ *In: Kroh, A. \& Reich, M. (Eds.) Echinoderm Research 2010: Proceedings of the Seventh European Conference on \\ Echinoderms, Göttingen, Germany, 2-9 October 2010. Zoosymposia, 7, xii +316 pp.
}

\begin{abstract}
Gauthieria mosae is recorded for the first time from upper Campanian (Belemnitella minor/Nostoceras polyplocum Zone) strata at the Teutonia Nord quarry in the Hannover area (northwest Germany), with two specimens available. This species was previously known only from the lower upper Campanian (basiplana/spiniger Zone and higher) of the province of Liège, northeast Belgium. In addition, a specimen of Gauthieria aff. pseudoradiata, from the B. minor/N. polyplocum Zone as well at the Teutonia Nord quarry, is illustrated and discussed in an attempt to elucidate the confused taxonomy of this form.
\end{abstract}

Key words: Echinoidea, Phymosomatidae, Cretaceous, Campanian, palaeogeography

\section{Introduction}

In recent decades, Upper Cretaceous rocks in the environs of Hannover, Lower Saxony (northwest Germany; Fig. 1) have yielded a wealth of regular and irregular echinoids. These species have been considered in numerous papers, both taxonomically and stratigraphically. For Late Cretaceous forms in general, reference is made to Ernst (1968, 1970a, 1970b, 1971a, 1971b, 1972, 1975), while Santonian faunas were described by Ernst (1973) and assemblages of Campanian age discussed and illustrated by Abu-Maaruf (1975), Schulz (1985), Niebuhr (1995) and Neumann et al. (2002). Specifically to the southeast of Hannover, at a number of large working quarries, highly fossiliferous from lower to upper Campanian strata (Sphenoceramus lingua/Gonioteuthis quadrata Zone to Belemnitella minor/Nostoceras polyplocum Zone; see Niebuhr 1995, Niebuhr \& Reich 2004 for details are accessible. These also include a wide array of echinoid taxa. Irregular echinoids in particular are very frequent (see Table 1); regulars are much less common (Table 2). The last, comprehensive, systematic treatment of Late Cretaceous phymosomatoid echinoid faunas from the area, and from northwest Germany in general, is that of Schlüter (1883). Only for northeast Germany, in the 'Schreibkreide' (White Chalk) of the Isle of Rügen (Vorpommern), are some more recent works available (Nestler 1966; Kutscher 1973, 1985a, 1985b, 1985c, 2003; Schlüter et al. 2012). 


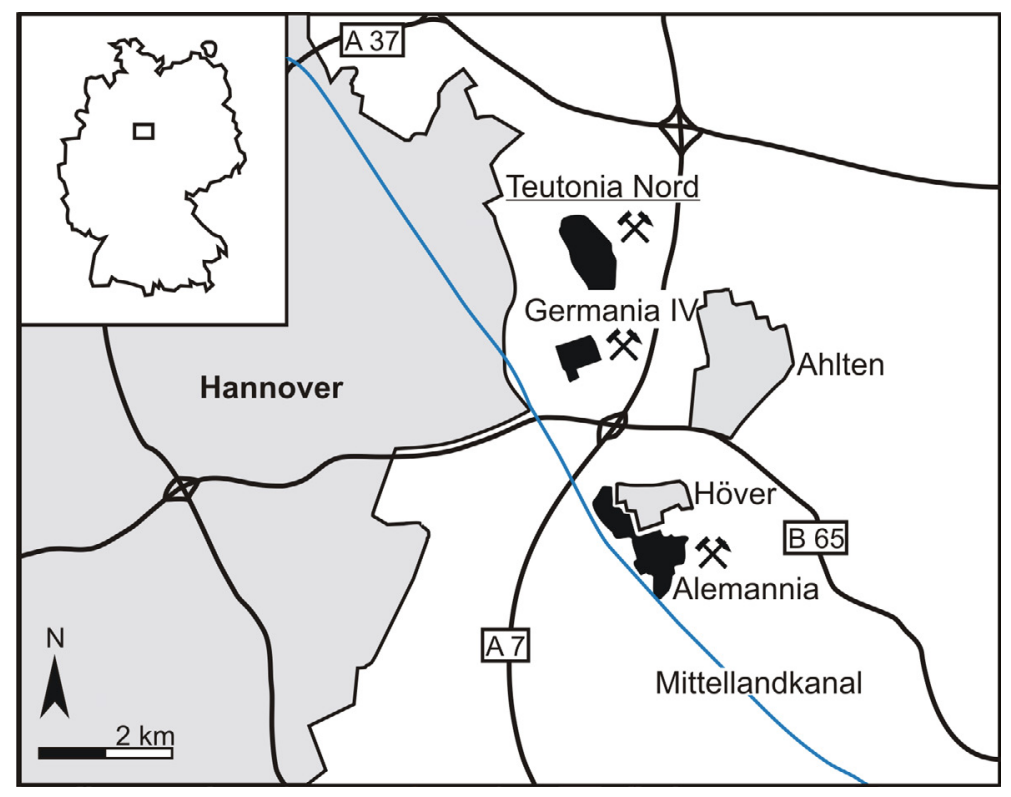

FIGURE 1. Sketch map of the southeastern margin of the Hannover city area with the position of the quarries exposing Campanian successions. The material studied here comes from the northern-most outcrop (Teutonia Nord quarry).

Seen in this light, it is not surprising that new collecting can produce rare or little-known echinoid taxa from the study area. Here, we illustrate and discuss new records of Gauthieria mosae Geys, 1980 and Gauthieria aff. pseudoradiata (Schlüter, 1883). So far, the former was exclusively known from the lower upper Campanian of the province of Liège, northeast Belgium. The latter is problematical in as far as its systematic assessment is concerned (see Jagt 2000), because Schlüter (1883) erected it without illustrating any specimen. We here hope to clarify the status of Schlüter's species.

Institutional abbreviations. To denote the repositories of specimens illustrated and/or referred to in the text, the following abbreviations are used: GZG, Geowissenschaftliches Zentrum der Universität Göttingen, Georg-August Universität, Göttingen, Germany; IRScNB, Institut royal des Sciences naturelles de Belgique, Brussels; NHM, The Natural History Museum, Department of Palaeontology, London; NHMM, Natuurhistorisch Museum Maastricht, Maastricht.

Systematic Palaeontology (following Kroh \& Smith 2010)

\section{Order Phymosomatoida Mortensen, 1904}

Family Phymosomatidae Pomel, 1883

Genus Gauthieria Lambert, 1888

Type species: Cyphosoma radiatum Sorignet, 1850, by original designation.

\section{Gauthieria mosae Geys, 1980}

Figures $2 \mathrm{~A}-\mathrm{H}, 3 \mathrm{G}$

Gauthieria? mosae-Geys 1980: 215, Figs. 5/1-3, 6/1 [with additional synonymy] Gauthieria mosae Geys, 1980_Jagt 2000: 233, Pl. 10, Figs. 8-11

Type. Holotype is IRScNB 10178 (IG 6521, Ubaghs Collection; Geys 1980: Figs. 5/1-3, 6/1).

Material. Two specimens (GZG.INV.15304-15305) from the upper Campanian B. minor/N. polyplocum Zone of the Teutonia Nord quarry, Misburg. 


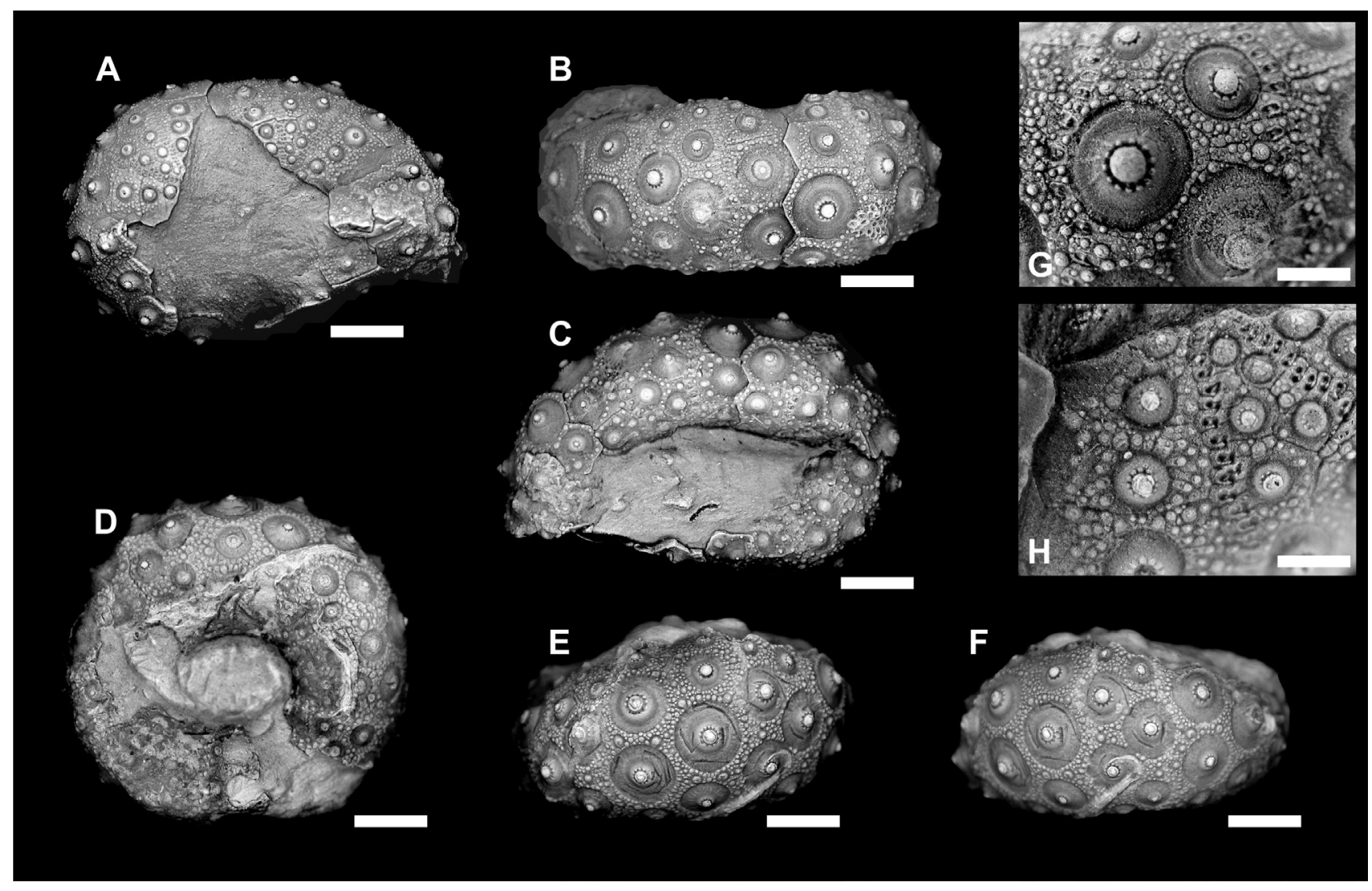

FIGURE 2. Gauthieria mosae Geys, 1980 (A-C, G-H: GZG.INV.15304; D-F: GZG.INV.15305), A. apical view; B. ambital view; C. oral view; D. oral view; E. view of ambital ambulacral plates; F. view of ambital interambulacral plates; G. detail of the ambital ambulacrum; H. detail of the adapical surface (Figs. A-F: scale bar $=5 \mathrm{~mm}$; G-H: scale bar = 2 mm).

Description. Tests medium sized (up to $25 \mathrm{~mm}$ in diameter); GZG.INV.15305 circular in outline and inflated in profile, although slightly deformed, GZG.INV.15304 heavily crushed. Peristome small (c. 22 per cent of test diameter), deeply invaginated; ambitus at mid-height. Only half of upper surface preserved, to apical opening in GZG.INV.15304; dimensions of apical opening thus unknown, approximated by the adapical remains of the test in specimen GZG.INV.15304 the apical opening has been large, at least $1 / 3$ of the test diameter; ambulacral and interambulacral plates next to peristome poorly preserved; exact number of tubercles per row of ambulacra and interambulacra unknown, but, as preserved, eight tubercles in each row; tubercles crenulate and imperforate; small buccal notches present.

Ambulacra uniserially throughout, tapering adorally and adapically; plates polyporous; at ambitus, arranged in arcs of 5-6 pore pairs, adapically in arcs of 3-4 per plate, and tubercles separated by simple elements (1-2); between each pore pair ambitally, a wide area occupied by $2-3$ minute granules and pore pairs are slightly inclined; pore pair inclination increases adorally. Tubercles separated by narrow, granulated area; extrascrobicular surface very small at ambitus and adorally, tubercles occupying most of plates; adapically, these areas become wider; tubercles largest at ambitus; adorally and adapically, size decrease very rapid. Perradius with small band of granules, interrupted faintly below ambitus, causing two adjacent areoles to become confluent.

Interambulacra wider than ambulacra (c. $36 \%$ at the ambitus); tubercles very large, occupying most of plates; at ambitus, significantly larger. Tubercles surrounded by very thin circle of small scrobicular granules; tubercle size decreasing abruptly above and below the ambitus, through increase of extrascrobicular surface adapically; mamelons very small compared to areole size; areole outline cir- 


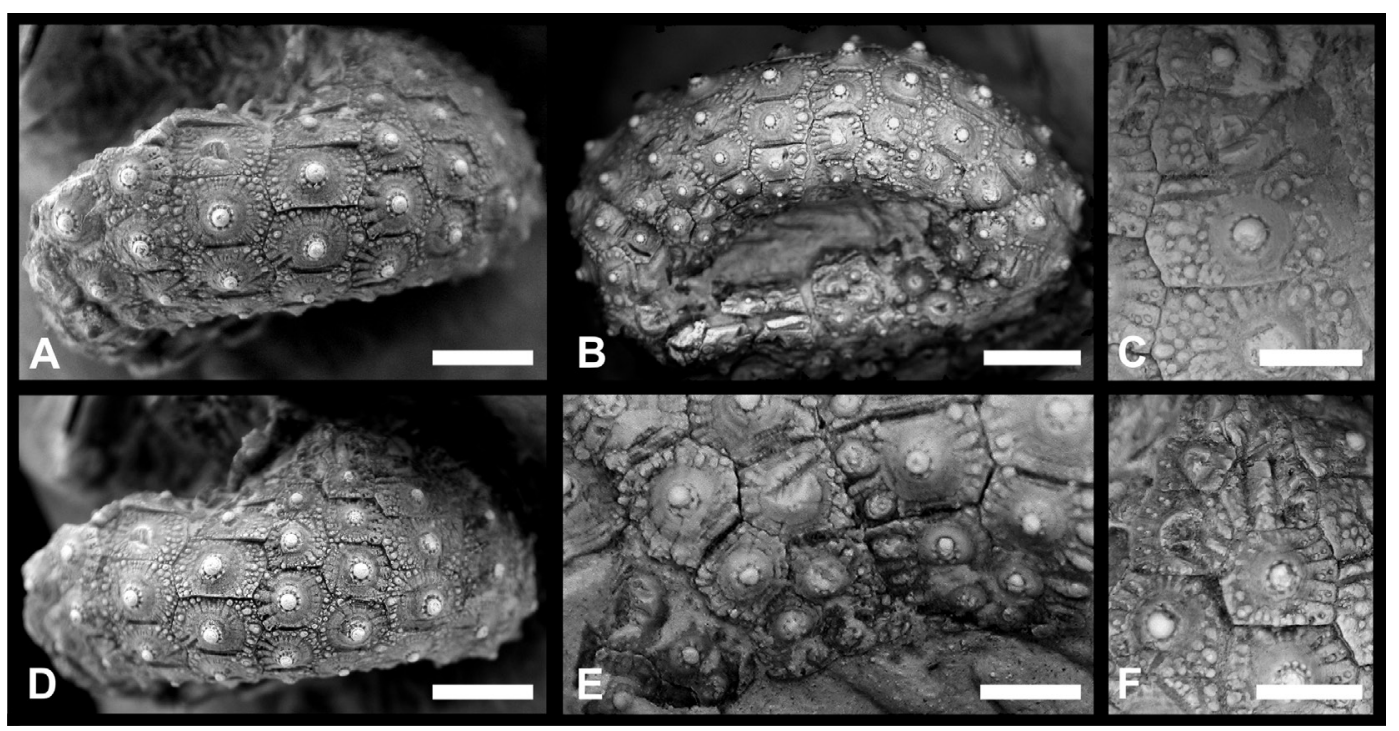

FIGURE 3. Gauthieria aff. pseudoradiata (Schlüter, 1883) (GZG.INV.15306). A. lateral view (interambulacrum); B. oblique lateral-oral view; C. detail of adapical interambulacrum; D. lateral view (ambulacrum); E. detail of adoral plating; F. detail of adapical ambulacrum; (Figs. A, B, D: scale bar $=5 \mathrm{~mm}$; Figs. C, E, F: scale bar $=2 \mathrm{~mm}$ ).

cular to oval (vertically elongated); at outer ring of tubercles, weak radiating striation seen; tubercles not confluent, separated by narrow zone of granules; adorally, secondary tubercles appear, becoming more prominent close to peristomal opening; a broad naked zone is present interradially above the ambitus (plate number could not observed due to imcompleteness).

Discussion. These specimens match the original description of Gauthieria mosae by Geys (1980), and a subsequent account by Jagt (2000) based on four additional tests (NHMM JJ 7457, NHMM JJ 7643, NHMM JJ 8257 and NHMM K 1001) from the same area as the holotype. The only difference is the separation of interambulacral tubercles in a series. In the holotype, the tubercles are separated by wide (tall) zones of granules; in our specimens, this zone is narrower. In other features, there is a good match, for instance in ambulacral structure, i.e., a comparable number of pore pairs per plate, large areoles separated by a wide granular space, inclination of pore pairs, prominent size of the interand ambulacral tubercles at the ambitus, plus the rapid size decrease adapically, plus a small, deeply sunken peristome. In addition, there are no secondary tubercles on the interambulacra adapically (see additional description of the holotype in Jagt 2000). However, the phymosomatoid plating style, as described in the holotype (Geys 1980), cannot be observed in the material described here. However, due to the overall similarity, we attribute our specimens to G. mosae; the minor differences discussed above are considered to be the result of intraspecific variation.

Gauthieria alterna (Kutscher, 1985c), from the lower Maastrichtian of Rügen (northeast Germany) and the uppermost Maastrichtian of Sjælland, eastern Denmark (Jagt et al. 1998), is closely similar in having tall ambulacral and interambulacral plates ambitally, which also rapidly decrease in size adapically. However, it differs in the number of pore pairs (3-4) and in showing an interradial granular zone in the interambulacra on the upper surface. Additionally, no simple elements could be observed between ambital ambulacral tubercles in G. alterna.

The view expressed by Jagt (2000) that Gauthieria mosae and G. middletoni (Woodward, 1856) (neotype is NHM E1514 designated by Smith \& Wright 1996) were not conspecific, an assumption made Smith \& Wright (1996), is adopted here. The latter has strongly developed secondary tubercles on the apical surface, a feature not seen in G. mosae (as additional preparation of the holotype by Jagt 
2000 has shown) and our specimens.

Occurrence. To date, G. mosae is known from the middle Zeven Wegen Member (Gulpen Formation, Galeola papillosa basiplana/Trachyscaphites spiniger Zone and higher; Jagt 1999) of Heure-le-Romain, Lixhe and Haccourt (province of Liège, northeast Belgium) and the upper Campanian B. minor/N. polyplocum Zone in the Hannover area (northwest Germany).

\section{Gauthieria aff. pseudoradiata (Schlüter, 1883)}

Figures 3A-F, 4A-B

Phymosoma pseudoradiatum-Schlüter, 1881: 216 [nomen nudum]; Schlüter, 1883: 24

Phymosoma pseudoradiatum Schlüter-non Ravn 1928, 58, P1. 6, Fig. 4 [= Gauthieria ? sp.]

Gauthieria pseudoradiata (Schlüter)—non Kongiel 1950, 314, Pl. 1, Figs. 5-8 [= Gauthieria ? sp.]; Geys 1980, 212, Figs. 3/7-9, 4/1-2; non Kutscher 1985c, 731, Pl. 1, Figs. 4-8 [=Cosmocyphus princeps]; ? van der Ham et al. 1987, $23, \mathrm{Pl}$.

4, Figs. 1-2; van der Ham \& van Birgelen 1992, 148, Pl. 2, Figs. 3-4; non Smith \& Wright 1996, 303, Pl. 106, Figs. 7-9; P1. 107, Figs. 2-3; P1. 113, Figs. 16-18; Text-fig. 109 [= Gauthieria ? sp.]; non Jeffery 1997, 674, P1. 4, Figs. 1-5, Text-figs. 6a-b [= Gauthieria ? sp.]; Smith \& Jeffery 2000, 93 [pars], non Fig. 36 a-b

Gauthieria pseudoradiata auctt., non Schlüter?-Jagt 2000, 233 [pars], Pl. 12, Figs. 2-11 [non Fig. 1]; Pl. 13, Figs. 1-2

Type. Schlüter (1883) failed to designate a type specimen, nor did he illustrate one. In the absence of Schlüter's original, a lectotype cannot be designated at this time, any material assigned to this species could not be located in Clemens A. Schlüter's remains so far (Rheinische Friedrich-Wilhelms-Universität, Institut für Paläontologie, Bonn, Germany).

Material. A single specimen (GZG.INV.15306) from the upper Campanian B. minor/N. polyplocum Zone of the Teutonia Nord quarry, Misburg.

Description. Unfortunately, the sole specimen available is strongly distorted, precluding any test measurements; maximum size (lengthwise) c. $29 \mathrm{~mm}$; oral side of test with a faint inclination towards peristome, suggesting peristome to have been sunken originally. Tubercles crenulate and imperforate; several fragments of slender spines associated, but poorly preserved; however, distinct fine striation seen.

Ambulacra with phymosomatoid plating style; true number of primary tubercles unknown due to fragmentary preservation, but c. 9-10 per column, similar to interambulacral primary tubercles; ambulacra tapering adapically and, less clearly, adorally; plates slightly wider than high and distinctly hexagonal in outline; sinuous poriferous zone strictly uniserial. Pore pairs horizontal, but more inclined towards peristome; plates invariably with 5 pore pairs, except for first 2 primary plates at apical opening ( 3 pore pairs each); plating style of ambulacra close to peristome not clearly seen, but fewer than 5 pore pairs present; extrascrobicular space narrow and with rather coarse granules; perradius with thin granular zone; tubercles contiguous in each row. Only above ambitus, each plate with thin line of granules at adapical margin, separating adjacent tubercles; areoles with radial grooves, best developed adradially.

Interambulacra with Around 10-11 tubercles per column; c. 31\% wider than the ambulacra, at the ambitus. Plates wider than high; at outer ring of areoles, well-developed radial striation seen; areoles confluent at and below ambitus; above, separated by small zone of granules, at adapical margin of each plate; secondary tubercles (2-3) developed only adradially below ambitus, becoming progressively more prominent towards peristome. Above ambitus, plates becoming lower through progressive growth of adradial granular zones. Right next to apical opening, granular zones narrower and tubercles move to adradial margin; above and beneath ambitus, tubercles decrease gradually in size; well-developed granular zone at interradius present at ambitus and below; above (after $7^{\text {th }}$ to $8^{\text {th }}$ 


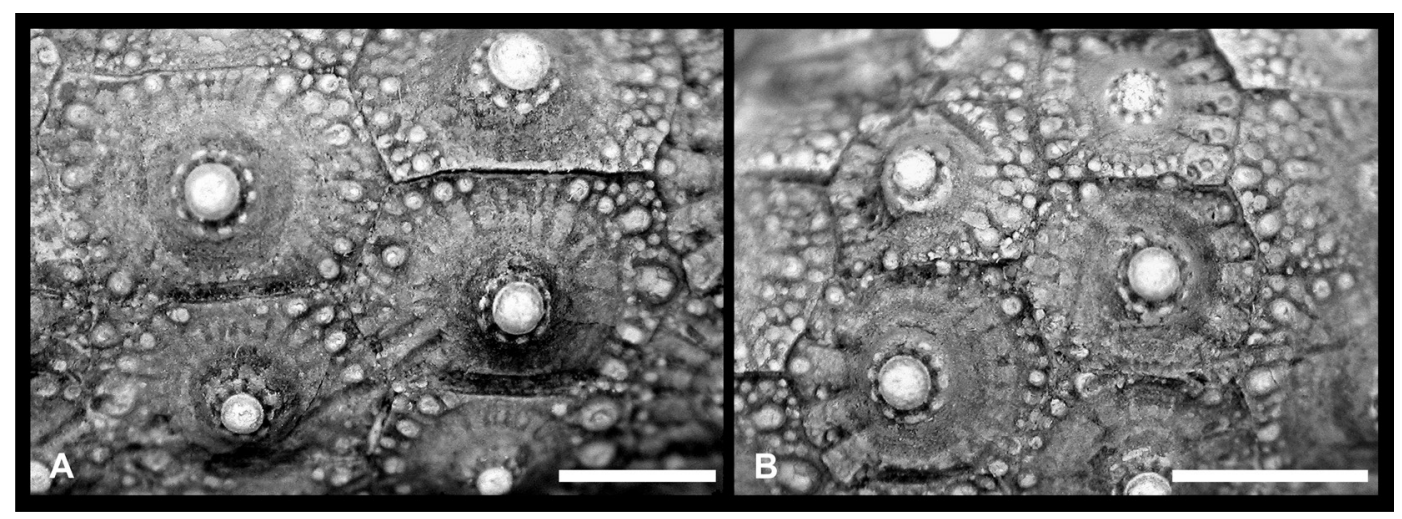

FIGURE 4. Gauthieria aff. pseudoradiata (Schlüter, 1883) (GZG.INV.15306). A. detail of ambital interambulacrum; B. detail of ambital ambulacrum (scale bar $=2 \mathrm{~mm}$ ).

plate), V-shaped naked zone seen.

Discussion. Ever since its erection, the interpretation of this species has proved to be difficult. Schlüter (1883: 24) failed to illustrate any specimen(s); his original description is as follows:

"Im Ober-Senon Norddeutschlands findet sich als Seltenheit ein Phymosoma, welches dem aus dem mittleren Turon-Pläner wohlbekannten Phymosoma radiatum nahe steht. Uebereinstimmend sind die Ambulacra, welche aus einfachen Porenpaaren gebildete, wellig gebogene Gänge darstellen, die sich weder am Munde noch am After durch auseinanderschieben verbreitern, übereinstimmend die Radiirung der Asseln, welche nur primäre, crenelierte, nicht durchbohrte Stachelwarzen tragen, denen sich an der Mundseite auf jedem Interambulacrum seitlich ein paar kleine Secundärhöckerchen anfügen etc. Abweichend ist die jüngere Art von der älteren dadurch, dass sich auf den Ambulacralasseln keine mehrfachen Horizontalreihen von Granulen finden, ... dann dadurch, dass auf der Oberseite des Gehäuses die Interambulacraltafeln niedriger und breiter sind, die Stachelwarzen (mit Ausnahme der äussersten) in das Centrum der Asseln rücken — während sie bei Phymosoma radiatum dem Seitenrande näher stehen — so dass die Felder hierdurch Raum für ein seitliches Granula-Band erhalten."

In other words, Schlüter's new species is very similar to the Turonian Gauthieria radiata (Sorignet, 1850) in the development of strictly uniserial, sinuous pore zones, the radial striation of the crenulate, imperforate tubercles and the occurrence of few adradial secondary tubercles on the adoral interambulacra. It deviates from the latter species by its larger test dimensions ( $27 \mathrm{~mm}$ diameter), the smaller and less sunken peristome and the lack of any multiple horizontal rows of granules between ambulacral tubercles. In addition, the adapical interambulacral plates are wider and less tall, and the tubercles of adapical interambulacra are in a more central position, except for the first plate at the apical opening.

Smith \& Wright (1996), however, correctly noted that striation of the tubercles was also present in juveniles of other phymosomatoids and, thus, could not be used as a diagnostic feature. The allegedly larger test size of G. pseudoradiata is an unreliable criterion as well, because G. radiata is also known to attain similar sizes (26.6 mm; Smith \& Wright 1996: 291).

However, GZG.INV.15306 is so close to Schlüter's description, that we think that this is the form that he had in mind when describing G. pseudoradiata. Unfortunately, the rather poor preservation of our specimen does not allow comparing all test features, such as size and degree of invagination of the peristome. On the other hand, Schlüter's description is only brief and lacks several, important details. For instance, there is no clear indication of whether the tubercles of the interambulacra or ambulacra are separated or confluent, of how many pore pairs are to be found in an ambulacral plate or whether 
or not any inclination of the pore pairs towards the peristome exists.

Additional evidence in favour of our interpretation comes from the locality and relative age of Schlüter's species; his specimens originated from Ahlten, which is in close proximity to Misburg (see Fig. 1). They were collected from the "... Kreidemergel mit Belemnitella mucronata..." (Schlüter 1883: 24), which indicates a late Campanian age.

At the time of Clemens A. Schlüter, three small quarries were accessible in the south of Ahlten, which probably exposed the upper "Mucronaten-Schichten" (Schlüter 1876: 510), which would then be the lower B. minor/N. polyplocum Zone (Ernst 1968: 242, precisely Ernst wrote lower minor Zone), according to a more modern stratigraphical concept. These outcrops yielded marly, spongiolithic limestones (“Opoka”) (Bettenstaedt \& Dietz 1957, Ernst 1968). The onset of the Opoka facies, however, appears at first at the upper B. minor/N. polyplocum Zone (Niebuhr 1995). Concluding is that the new find of our supposed Gauthieria aff. pseudoradiata is of a similar stratigraphic level (more detailed stratigraphic informations of the here presented specimen are not available, probably lower to middle B. minor/N. polyplocum Zone) but differs in its lithological provenance (non-spiculitic, marly limestones).

Jagt (2000) described and illustrated various tests from the Maastrichtian type area, which are very similar to our specimen. Additionally, he stated that his material corresponded more closely to Schlüter's original description than to specimens described by Smith \& Wright (1996). In Jagt's (2000) material areoles in interambulacra are confluent; in ambulacra, ambital and subambital areoles are confluent, while adapical ones are separated by a narrow row of granules of various sizes. Pore pairs close to the peristome are markedly inclined and form a kind of phyllode.

Provisionally, Gauthieria pseudoradiata is here understood as a species with confluent tubercles in ambital ambulacra and interambulacra and with distinctly inclined pore pairs towards the peristome. Although the latter feature was not mentioned by Schlüter (1883), he additionally mentioned that specimens of Gauthieria radiata from the Upper Cretaceous of Meudon (France) ("... Kreide mit Belemnitella mucronata...", i.e., upper Campanian), described and figured by Cotteau (1864: 609, Pl. 1148, Figs. 11-14), might belong to G. pseudoradiata. As the illustrations are too small and show only the general habitus (Cotteau 1864: Pl. 1148, Figs. 11-13), Schlüter's assumption cannot be substantiated. However, Fig. 14 in Cotteau (1864: P1. 1148) shows a detail of conjoint interambulacral plates of one row and one ambulacral plate (assumedly an ambital one, judging by the number of pore pairs, 5); between these interambulacral plates, there are no obvious granular zones, not at the upper nor at the lower margin. In view of the fact that this illustration fits the general idea of Schlüter's rendition of G. pseudoradiata, it does support the interpretation of that species as here favoured.

However, Smith \& Wright (1996) stated that the type of Gauthieria broecki Lambert, 1897—which they synonymised with their interpretation of Gauthieria pseudoradiata (Schlüter, 1883) —would be from Meudon, France illustrated by Cotteau (1864: 609, Pl. 1148, Figs. 11-14), the same specimen assumed by Schlüter (1883) to be conspecific with his Phymosoma pseudoradiatum. This cannot be traced, as Lambert (1898: 152, P1. 4, Figs. 1-5) illustrated a specimen from the lower Danian of Ciply ("podingue de la Malogne"). Gauthieria broecki Lambert, 1898, however, seems to differ from the description of Schlüter's P. pseudoradiatum in having broad granular zones between the ambulacral tubercles and thus is closer to Gauthieria radiata (Sorignet, 1850) (compare Geys 1980: 210). Geys (1980) considered G. broecki as a supspecies of the Turonian G. radiata due to their large morphological overlap. However, the type of Gauthieria broecki is only poorly preserved (Geys 1980: 212) and thus the taxonomic status of this species should be re-examined in detail. 


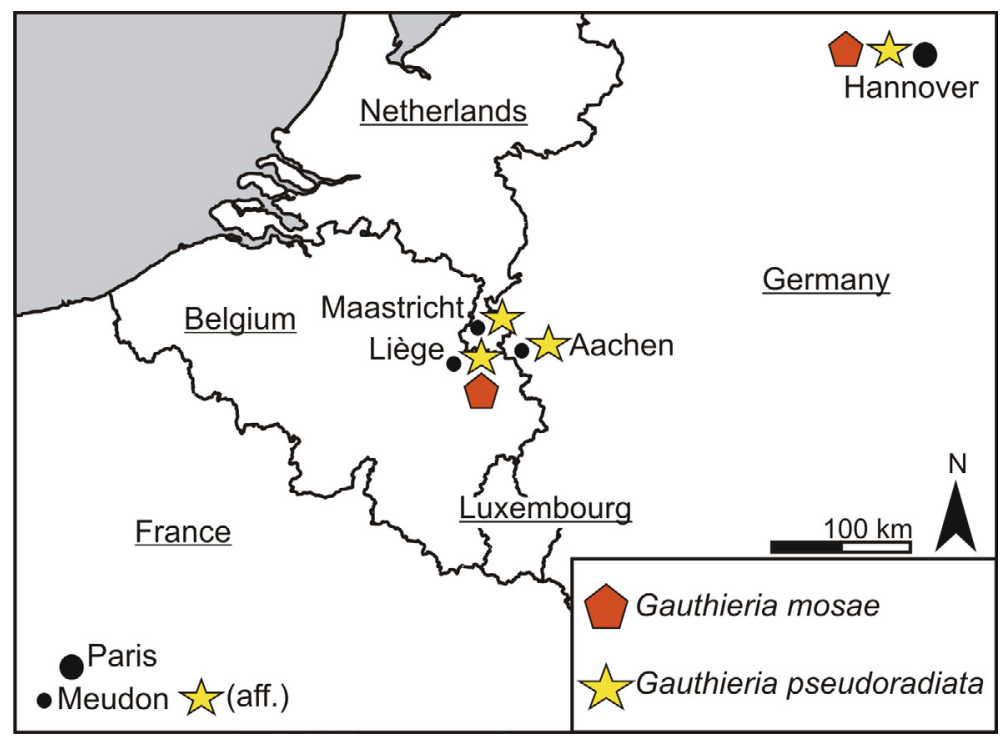

FIGURE 5. Geographical distribution of Gauthieria mosae and Gauthieria aff. pseudoradiata.

Another phymosomatoid from the Campanian and Maastrichtian that has often been attributed to G. pseudoradiata (e.g., Smith \& Wright 1996) is definitely very similar to G. radiata. This form is also found in the Campanian of the Hannover area, which in part could explain the confusion surrounding G. pseudoradiata; such tests do significantly deviate from Schlüter's description in showing multiple horizontal rows of granules. In addition, a biserial pore arrangement is occasionally present adapically in specimens of the small forms of the Hannover area, which is different to Gauthieria radiata. These small forms do probably relate to Lambert's description of Gauthieria broecki (1898) but there is still need for discussion (see above) and thus they are here provisionally treated as separated.

Gauthieria wetherelli (Woodward, 1856) (see Smith \& Wright 1996: 298, Pl. 100, Figs. 7-12; P1. 109, Figs. 3-4, 6; Text-fig. 107) also shows some striation in interambulacral areoles. However, it has relatively broad horizontal zones of granules between ambulacral plates and develops small secondary adradial tubercles in interambulacra adorally, and thus differs from the original description of Schlüter for G. pseudoradiata (1883) and the specimen described here.

TABLE 1. List of irregular echinoids from the Hannover area (after Neumann et al. 2002); ${ }^{\text {a }}$ according to Smith \& Wright (2003), these taxa are forms of Echinocorys scutata Leske, 1778.

Echinoneoida Clark, 1925

Conulus matesovi Poslavskaya \& Moskvin in Moskvin, 1959

Galerites ernsti Schulz, 1985

Galerites roemeri (Desor in Agassiz \& Desor, 1847)

Galerites vulgaris (Leske, 1778)

Galerites sulcatoradiatus (Goldfuss, 1829)

Cassiduloida Agassiz \& Desor, 1847

Echinogalerus peltiformis (Wahlenberg, 1821)

Echinogalerus? hannoniensis (Lambert, 1911)

Holasteroida Durham \& Melville, 1957

Hagenowia blackmorei Wright \& Wright, 1949

Offaster pilula (Lamarck, 1816)

Offaster aff. pomeli Munier-Chalmas in Dru, 1884

Galeola senonensis (d'Orbigny, 1855)

Galeola papillosa papillosa (Leske, 1778)

Galeola papillosa basiplana Ernst, 1971 ${ }^{\mathrm{a}}$
Echinocorys gr. conica (Agassiz in Agassiz \& Desor, $1847)^{\mathrm{a}}$

Echinocorys gr. 'gibba/marginata'a

Echinocorys subglobosa (Goldfuss, 1829) ${ }^{\mathrm{a}}$

Echinocorys pyramidata (Portlock, 1843) a

Plesiocorys gr. lehmanni/heberti

Cardiaster cordiformis (Woodward, 1833)

Spatangoida Agassiz, 1840

Hemiaster aquisgranensis Schlüter, 1899

Peroniaster cotteaui Gauthier in Peron, 1887

Micraster fastigatus Gauthier in Peron, 1887 (sensu

Stokes, 1975) (= M. gibbus sensu auctorum)

Micraster gr. schroederi/glyphus

Micraster stolleyi (Lambert in de Grossouvre, 1901)

Diplodetus cretaceus Schlüter, 1870

Diplodetus sp. 
Occurrence. Upper Campanian (B. minor/N. polyplocum Zone), Teutonia Nord quarry, Misburg; ?Vaals Formation (lower lower to lower upper Campanian), Vijlen, Lixhe and Lanaye members (Gulpen Formation; upper lower to uppermost Maastrichtian), Valkenburg, Gronsveld, Emael, Nekum and Meerssen members, plus Kunrade Limestone facies of Maastricht Formation (upper Maastrichtian), CPL SA-Haccourt, CBR-Lixhe, CBR-Romontbos, Ankerpoort-Marnebel, Mesch, Altembroeck, Snouwenberg (northeast Belgium), ENCI-HeidelbergCement Group quarry (southeast Netherlands) and Aachen-Schneeberg (Germany) (Geys 1980; van der Ham \& Birgelen 1992; Jagt 2000), ? "Senonian" of Meudon, France (Schlüter 1883).

\section{Palaeogeographical implications}

The present material of Gauthieria mosae significantly extends the geographical range of this species, from the province of Liège in northeast Belgium (Heure-le-Romain, Haccourt and Lixhe). In contrast, the distribution area of G. pseudoradiata is considerably reduced by our revised records from the Hannover area and from the type area of the Maastrichtian Stage in the southeast Netherlands, northeast Belgium and the Aachen area in Germany (Fig. 5) and according to Schlüter's assumption (1883) Meudon, France, also. This species has often been misinterpreted in the literature, which explains why it was recorded from a much wider area, i.e., western Europe to western Asia (compare Smith \& Jeffery 2000).

\section{Acknowledgements}

We are grateful to the reviewers Andreas Kroh (Vienna) and John Jagt (Maastricht) for their helpful comments, which improved the manuscript considerably. In addition, J. Jagt is thanked for corrections and polishing the english. Sandra Kaiser is thanked for supplying informations on existing material of Clemens A. Schlüter in the collections of the Rheinische Friedrich-Wilhelms-Universität, Institut für Paläontologie, Bonn, Germany.

TABLE 2. List of regular echinoids from the Hannover area (modified after Frerichs 2005; Krupp 2006; Schlüter et al. 2012; *present paper and pers. obs.).

\begin{tabular}{cc}
\hline Cidaroida Claus, 1880 & Phymosoma koenigii (Mantell, 1822) \\
Temnocidaris (Stereocidaris) sceptrifera (Mantell, & Gauthieria mosae Geys, 1980* \\
1822) & Gauthieria aff. pseudoradiata (Schlüter, 1883)* \\
Temnocidaris (Stereocidaris) cf. hagenowi (Desor, & Cosmocyphus princeps (von Hagenow, 1840)* \\
1858) & Diplotagma altum Schlüter, 1883 \\
Temnocidaris (Hirudocidaris) hirudo (Sorignet, 1850) & Salenioida Delage \& Hérouard, 1903 \\
Phalacrocidaris cf. merceyi? (Cotteau, 1862) & Pleurosalenia heberti (Cotteau, 1861) \\
Phymosomatoida Mortensen, 1904 & Bathysalenia granulosa (Woodward, 1856) \\
Phymosoma ravni Schlüter, Kutscher, Smith, Jagt \& Lees, & Temnopleuroida Mortensen, 1943 \\
2012 (= Cyphosoma granulosum sensu Cotteau, 1864) & Boletechinus rowei (Gregory, 1900) \\
\hline
\end{tabular}




\section{References}

Abu-Maaruf, M. (1975) Feingliederung und Korrelation der Mergelkalk-Fazies des Unter-Campan von Misburg, Höver und Woltorf im ostniedersächsischen Becken. Berichte der Naturhistorischen Gesellschaft Hannover, 119, $127-204$.

Agassiz, L. (1840) Catalogus systematicus Ectyporum Echinodermatum fossilium Musei Neocomiensis, secundum ordinem zoologicum dispositus; adjectis synonymis recentioribus, nec non stratis et locis in quibus reperiuntur. Sequuntur characteres diagnostici generum novorum vel minus cognitorum. Oliv. Petitpierre, Neuchâtel, 20 pp.

Agassiz, L. \& Desor, E. (1847) Catalogue raisonné des espèces, des genres, et des familles d'échinides. Annales des Sciences Naturelles, 3(7), 129-168.

Bettenstaedt, F. \& Dietz, C. (1957) Tektonische und erdölgeologische Untersuchungen im Raum Lehrte östlich Hannover. Geologisches Jahrbuch, 74, 463-522.

Clark, H.L. (1925) A Catalogue of the Recent Sea-Urchins (Echinoidea) in the Collection of the British Museum (Natural History). British Museum (Natural History), London, $250 \mathrm{pp}$.

Claus, C.F.W. (1880) Grundzüge der Zoologie (4 ${ }^{\text {th }}$ edition). N.G. Elwert'sche Universitätsbuchhandlung, Marburg/Leipzig, vii $+821 \mathrm{pp}$.

Cotteau, G. (1861-1867) Paléontologie Française. Description des animaux invertébrés commencée par Alcide d'Orbigny continuée sous la direction d'un comité spécial. Terrain crétacé, 7. Échinides. Masson, Paris, 894 pp.

Delage, Y.M. \& Hérouard, E. (1903) Traité de Zoologie concrète 3, Les échinodermes. Librairie C. Reinwald, Paris, 496 pp.

Desor, E. (1855-1858) Synopsis des échinides fossiles. Ch. Reinwald/Kriedel \& Niedner, Paris/Wiesbaden, lxviii+ $490 \mathrm{pp}$.

Durham, J.W. \& Melville, R.V. (1957) A classification of echinoids. Journal of Paleontology, 31, $242-272$.

Ernst, G. (1968) Die Oberkreide-Aufschlüsse im Raume Braunschweig-Hannover und ihre stratigraphische Gliederung mit Echinodermen und Belemniten, 1. Teil: Die jüngere Oberkreide (Santon-Maastricht). Berichte der Naturwissenschaftlichen Gesellschaft Hannover, Beiheft 5, 235-284.

Ernst, G. (1970a) Faziesgebundenheit und Ökomorphologie bei irregulären Echiniden der nordwestdeutschen Oberkreide. Paläontologische Zeitschrift, 44, 41-62.

Ernst, G. (1970b) Zur Stammesgeschichte und stratigraphischen Bedeutung der Echiniden-Gattung Micraster in der nordwestdeutschen Oberkreide. Mitteilungen aus dem Geologisch-Paläontologischen Institut der Universität Hamburg, 39, 117-135.

Ernst, G. (1971a) Biostatistische Untersuchungen über die Ontogenie und Phylogenie der Offaster/Galeola-Stammesreihe aus der borealen Oberkreide. Neues Jahrbuch für Geologie und Paläontologie, Abhandlungen, 139, $169-225$.

Ernst, G. (1971b) Die Entwicklung der hochspezialisierten Echiniden-Reihe Infulaster-Hagenowia in der borealen Kreide. Paläontologische Zeitschrift, 45, 120-143.

Ernst, G. (1972) Grundfragen der Stammesgeschichte bei irregulären Echiniden der nordwesteuropäischen Oberkreide. Geologisches Jahrbuch, A4, 63-175.

Ernst, G. (1973) Die Echiniden-Fauna des Santon der Gehrdener Berge. Berichte der Naturhistorischen Gesellschaft Hannover, 117, 79-102.

Ernst, G. (1975) Stratigraphie, Fauna und Sedimentologie der Oberkreide von Misburg und Höver bei Hannover. Mitteilungen aus dem Geologisch-Paläontologischen Institut der Universität Hamburg, 44, 67-97.

Frerichs, U. (2005) Seeigel. In: Amme, R. (Ed.), Fossilien aus dem Campan von Hannover. Arbeitskreis Paläontologie Hannover, Hannover, pp. 30-41.

Gauthier, V. (1887) Description des espèces de la Craie de Reims et de quelques espèces nouvelles de l'Aube et de l'Yonne. In: Peron, A. (Ed.), Notes pour servir à l'histoire du terrain de Craie. Bulletin de la Société des Sciences historiques et naturelles de l'Yonne, 41, 367-399.

Geys, J.F. (1980) Phymosomatoid echinoids from the Campanian and the Maastrichtian of Belgium and the Netherlands. Paläontologische Zeitschrift, 54, 199-224.

Goldfuss, A. 1826-(1829) Petrefacta Germanice tam ea, quae in Museo Universitatis Regiae Borussicae Fridericiae Wilhelmiae Rhenanae servantur, quam alia quaecunque in Museis Hoeninghusiano Muensteriano aliisque extant, Iconibus et Descriptionibus illustrata. Abbildungen und Beschreibungen der Petrefacten Deutschlands und der angränzenden Länder, unter Mitwirkung des Herrn Grafen Georg zu Münster. Arnz \& Co., Düsseldorf, 1(1): viii+1-76 (1826), 1(2): 77-164 (1829).

Gregory, J.W. (1900) Appendix A. Zeuglopleurus rowei, n. sp. In: Rowe, A.W. (Ed.), The zones oft he White Chalk of the English Coast, I. Kent and Sussex. Proceedings of the Geologists'Association, 16, 353-354.

Grossouvre, A. de (1901) Recherches de la Craie supérieure, 1. Stratigraphie générale, avec une Monographie du genre Micraster, par J. Lambert. Mémoire du Service pour la Carte géologique détaillée de France, viii + 1013 pp.

Hagenow, F. von. (1840) Monographie der Rügen'schen Kreideversteinerungen, II. Abtheilung Radiarien und Annulaten. Nebst Nachträgen zur ersten Abtheilung. Neues Jahrbuch für Mineralogie, Geognosie, Geologie und Petrefaktenkunde, [1840], 630-672. 
Ham, R.W.J.M. van der, de Wit, W., Zuidema G. \& van Birgelen, M. (1987) Zeeëgels uit het Krijt en Tertiair van Maastricht, Luik en Aken. Een atlas van de zeeëgels uit het Campaniën, Maastrichtiën en Daniën van Zuid-Limburg en aangrenzende delen van België en Duitsland. Publicaties van het Natuurhistorisch Genootschap in Limburg, 36, 1-92.

Ham, R.W.J.M. van der \& van Birgelen, M. (1992) Zeeëgels uit het Maastrichtien van de Schneeberg en omgeving (Aken, Duitsland). Natuurhistorisch Maandblad, 81, 139-153.

Jagt, J.W.M. (1999) Late Cretaceous-Early Palaeogene echinoderms and the K/T boundary in the southeast Netherlands and northeast Belgium - Part 1. Introduction and stratigraphy. Scripta Geologica, 116, 1-57.

Jagt, J.W.M. (2000) Late Cretaceous-Early Palaeogene echinoderms and the K/T boundary in the southeast Netherlands and northeast Belgium - Part 4: Echinoids. Scripta Geologica, 121, 138-375.

Jagt, J.W.M., Andersen, S.B. \& Jakobsen, S.L. (1998) The echinoid Gauthieria alterna from the uppermost Maastrichtian of Denmark. Bulletin of the Geological Society of Denmark, 45, 23-26.

Jeffery, C.H. (1997) All change at the Cretaceous-Tertiary boundary? Echinoids from the Maastrichtian and Danian of the Mangyshlak Peninsula, Kazakhstan. Palaeontology, 40, 659-712.

Kongiel, R. (1950) O kilku nowych jeżowcach z górnego mastrychtu okolic Puław. Acta Geologica Polonica, 1(3), 311-329. [In Polish with French summary]

Kroh, A. \& Smith, A.B. (2010) The phylogeny and classification of post-Palaeozoic echinoids. Journal of Systematic Palaeontology, 7, 147-212.

Krupp, R. (2006) Patagiosites stobaei und Phymosoma koenigi aus dem Campan von Misburg. Arbeitskreis Paläontologie Hannover, 34, 113-118.

Kutscher, M. (1973) Die regulären Echiniden der weissen Schreibkreide (Unter-Maastricht) der Insel Rügen. Der Aufschluss, 24, 107-115.

Kutscher, M. (1985a) Neue Echiniden aus dem Unter-Maastricht der Insel Rügen, Vertreter der Ordnungen Echinothurioida Claus, 1880, Diadematoida Duncan, 1889 und Phymosomatoida Mortensen, 1904. Zeitschrift für Geologische Wissenschaften, 13, 235-247.

Kutscher, M. (1985b) Neue Echiniden aus dem Unter-Maastricht der Insel Rügen, Vertreter der Phymosomatidae Pomel, 1883. Zeitschrift für Geologische Wissenschaften, 13, 521-532.

Kutscher, M. (1985c) Neue Echiniden aus dem Unter-Maastricht der Insel Rügen, Weitere Vertreter der Phymosomatidae Pomel, 1883. Zeitschrift für Geologische Wissenschaften, 13, 731-740.

Kutscher, M. (2003) Bestimmungsschlüssel der Seeigel (Echinoidea) der Weißen Schreibkreide (Kreide, Unter-Maastrichtium) von Rügen (Deutschland) und Møn (Dänemark). Erratica, 5, 3-41.

Lamarck, J.P. de (1816) Histoire naturelle des animaux sans vertèbres, ou tableau géneral des classes, des ordres, et des genres de ces animaux présentant les caractères généraux et particulières de ces animaux, leur distribution, leur classes, leurs familles, leurs genres et la citation des principales espèces qui s'y rapportent; précédée d'une introduction offrant la détermination des caractères essentiels de l'animal, sa distinction du végétal et des autres corps naturels, enfin, l'exposition des principes fondamentaux de la ....... 3. Les échinides. Déterville \& Verdière, Paris, 59 pp.

Lambert, J. (1888) Note sur un nouveau genre d'échinide de la craie de l'Yonne. Bulletin de la Société des Sciences historiques et naturelles de l'Yonne, 42, 3-14.

Lambert, J. (1898) Note sur les Échinides de la craie de Ciply. Bulletin de la Société belge de Géologie, de Paléontologie et d'Hydrologie, 11[for 1897], 141-190.

Lambert, J. (1911) Description des Échinides crétacés de la Belgique principalement de ceux conservés au Musée royal de Bruxelles. II. Échinides de l'étage Sénonien. Mémoires du Muséum royal d'Histoire naturelle de Belgique, 4, 1-81.

Leske, N.G. (1778) Jacobi Theodori Klein Naturalis dispositio Echinodermatum, edita et descriptionibus novisque inventis et synonymis auctorum aucta. G.E. Beer, Lipsiae (Leipzig), xxii + 278 pp.

Mantell, G.A. (1822) The Fossils of the South Downs, or Illustrations of the Geology of Sussex. Lupton Relfe, London, $327 \mathrm{pp}$.

Mortensen, T. (1904) The Danish Expedition to Siam, 1899-(1900) II. Echinoidea 1. Kongelige danske Videnskabernes Selskab Skrifter (7), 1, 1-124.

Mortensen, T. (1943) A monograph of the Echinoidea, III. 2. Camarodonta I. Orthopsidae, Glyphocyphidae, Temnopleuridae and Toxopneustidae. Reitzel, Copenhagen, vii $+553 \mathrm{pp}$.

Munier-Chalmas in Dru, L. (1884) Note sur la géologie et l'hydrologie de la région du Bechtaou (Russie - Caucase). Bulletin de la Société géologique de France, 3ème série, 12, 474-515.

Nestler, H. (1966) Echiniden aus dem Unter-Maastricht der Insel Rügen III. Gauthieria radiata. Geologie, 15, 1214-1221.

Neumann, C., Jagt, J.W.M. \& van der Ham, R.W.J.M. (2002) Rare Campanian echinoids from Höver and Misburg (Hannover area, Lower Saxony, Germany). Mitteilungen des Museums für Naturkunde Berlin, Geowissenschaftliche Reihe, $5,119-137$.

Niebuhr, B. (1995) Fazies-Differenzierungen und ihre Steuerungsfaktoren in der höheren Oberkreide von S-Niedersachsen/Sachsen-Anhalt (N-Deutschland). Berliner geowissenschaftliche Abhandlungen, A174, 1-131.

Niebuhr, B. \& Reich, M. (2004) Exkursion 7: Das Campan (höhere Ober-Kreide) der Lehrter Westmulde bei Hannover. 
In: Reitner, J., Reich, M. \& Schmidt, G. (Eds.), Geobiologie 2. 74. Jahrestagung der Paläontologischen Gesellschaft, Göttingen, 02. bis 08. Oktober (2004) Exkursionen und Workshops. Universitätsdrucke Göttingen, Göttingen, pp. 193-210.

Orbigny, A.D. d'. 1854-(1860) Paléontologie Française. Terrains crétacés, Tome 6. Échinodermes, Masson, Paris, pp. 1-96 (1854); 97-272(1855); 273-352 (1856); 353-384 (1857); 385-400 (1858); 401-432 (1858); 433-596 (1860).

Pomel, A. (1883) Classification méthodique et genera des échinides, vivants et fossils. A. Jourdan, Alger, $131 \mathrm{pp}$.

Poslavskaya, N.A. \& Moskvin, M.M. (1959) Klass Echinoidea. In: Moskvin, M.M. (Ed.), Atlas verkhnemelovoj fauny severnogo Kavkaza u Kryma. Gostoptechisdat, Moskva, pp. 237-304. [In Russian].

Portlock, J.E. (1843) Report on the geology of the County of Londonderry, and of parts of Tyrone and Fermanagh, examined and described under the authority of the Master-General and Board of Ordnance. A. Milliken, Dublin, xxxii $+784 \mathrm{pp}$.

Ravn, J.P.J. (1928) De regulære Echinider i Danmarks Kridtaflejringer. Kongelige danske Videnskabernes Selskab Skrifter, naturvidenskabernes-mathematiske Afdeling, 9, 1-63.

Schlüter, C. (1870) Bericht über eine geognostisch-paläontologische Reise im südlichen Schweden. Neues Jahrbuch für Mineralogie, Geologie und Paläontologie, [1870], 929-969.

Schlüter, C. (1876) Verbreitung der Cephalopoden in der oberen Kreide Norddeutschlands. Zeitschrift der Deutschen geologischen Gesellschaft, 28, 457-518.

Schlüter, C. (1881) Ueber die Vertikalverbreitung der fossilen Diadematiden und Echiniden im nördlichen Deutschland. Sitzungsberichte der niederrheinischen Gesellschaft für Natur- und Heilkunde, [1881], 213-218.

Schlüter, C. (1883) Die regulären Echiniden der norddeutschen Kreide. I. Glyphostoma (Latistellata). Abhandlungen der königlich Preussischen geologischen Landesanstalt, 4, iv +72 pp.

Schlüter, C. (1899) Ueber einige von Goldfuss beschriebene Spatangiden. II. Stück. Zeitschrift der Deutschen geologischen Gesellschaft, 51, 104-124.

Schlüter, N., Kutscher, M., Smith, A.B., Jagt, J.W.M. \& Lees, J.A. (2012) Late Cretaceous phymosomatids and the true identity of Cidarites granulosus Goldfuss, 1829 (Echinoidea, Phymosomatoida). Zootaxa, 3271, 17-30.

Schulz, M.-G. (1985) Die Evolution der Echiniden-Gattung Galerites im Campan und Maastricht Norddeutschlands. Geologisches Jahrbuch, A80, 3-93.

Smith, A.B. \& Jeffery, C.H. (2000) Maastrichtian and Palaeocene echinoids: a key to world faunas. Special Papers in Palaeontology, 63, 1-406.

Smith, A.B. \& Wright, C.W. (1996) British Cretaceous echinoids. Part 4, Stirodonta 3 (Phymosomatidae, Pseudodiadematidae) and Camarodonta. Monograph of the Palaeontographical Society London, 150(602), 268-341.

Smith, A.B. \& Wright, C.W. (2003) British Cretaceous echinoids. Part 7, Atelostomata, 1. Holasteroida. Monograph of the Palaeontographical Society London, 156(619), 440-568.

Sorignet, L.A. (1850) Oursins fossiles de deux arrondissements du Département de l'Eure (Louviers et Andelys). Barbaret, Vernon, iv +83 pp.

Stokes, R.B. (1975) Royaumes et provinces fauniques du Crétacé établis sur la base d'une étude systématique du genre Micraster. Mémoires du Muséum national d'Histoire naturelle, nouvelle série, C31, 1-94.

Wahlenberg, G. (1821) Petrificata telluris Suecanae. Nova Acta Societatis Regiae scientiarum upsaliensis, 8[1818], 1-116.

Woodward, S. (1833) An outline of the geology of Norfolk. John Stacy, Norwich/Longman \& Co., London, 55 pp.

Woodward, S.P. (1856) Appendix to deacde V. Memoirs of the Geological Survey of the United Kingdom, [1856], 1-7.

Wright, C.W. \& Wright, E.V. (1949) The Cretaceous echinoid genera lnfulaster Desor and Hagenowia Duncan. Annals and Magazine of Natural History, 2(12), 454-474. 